\title{
Reduction of polycyclic aromatic hydrocarbons promoted by cobalt or manganese nanoparticles
}

\author{
Fabiana Nador $^{\mathrm{a}}$, Yanina Moglie ${ }^{\mathrm{a}}$, Cristian Vitale ${ }^{\mathrm{a}}$, Miguel Yus ${ }^{\mathrm{b}}$, Francisco Alonso ${ }^{\mathrm{b}}$, Gabriel Radivoy ${ }^{\mathrm{a}, *}$ \\ ${ }^{a}$ Departamento de Química, Instituto de Química del Sur (INQUISUR-CONICET), Universidad Nacional del Sur, Avda. Alem 1253, 8000 Bahía Blanca, Argentina \\ ${ }^{\mathrm{b}}$ Departamento de Química Orgánica, Facultad de Ciencias, and Instituto de Síntesis Orgánica (ISO), Universidad de Alicante, Apdo. 99,03080 Alicante, Spain
}

\section{A R T I C L E I N F O}

Article history:

Received 1 March 2010

Received in revised form 3 April 2010

Accepted 6 April 2010

Available online $\mathrm{xxx}$

Dedicated to Professor María Teresa Chicote on the occasion of her 60th birthday

\section{Keywords:}

Cobalt

Manganese

Nanoparticles

Reduction

Polycyclic aromatic hydrocarbons

\begin{abstract}
A B S T R A C T
A new methodology for the partial reduction of polycyclic aromatic and heteroaromatic hydrocarbons under mild reaction conditions is presented, the process being a reasonable alternative to the catalytic hydrogenation or the Birch reaction. The reduction protocol described is based on the use of cobalt or manganese nanoparticles generated in situ in a simple and economic way, by reduction of commercially available $\mathrm{CoCl}_{2} \cdot 6 \mathrm{H}_{2} \mathrm{O}$ or $\mathrm{MnCl}_{2} \cdot 2 \mathrm{H}_{2} \mathrm{O}$ in the presence of lithium sand and the corresponding $\mathrm{PAH}$, acting itself as an electron carrier. The use of a deuterium-oxide-containing cobalt(II) salt allows the simple preparation of deuterium labeled products. The regiochemistry and degree of reduction in the case of 1-substituted naphthalene derivatives markedly depends on the nature of the metal-NPs used.
\end{abstract}

(ㄷ) 2010 Elsevier Ltd. All rights reserved.

\section{Introduction}

Polycyclic aromatic hydrocarbons (PAHs) are a class of hazardous organic compounds, which are considered priority pollutants due to their carcinogenic properties ${ }^{1}$ and their wide distribution in terrestrial and aquatic environments. They can be found as components of coal tar, creosote and crude oil, and are also produced from incomplete combustion of fossil fuels. ${ }^{2}$ The wide occurrence and potentially toxic effects of PAHs and their metabolites have attracted the interest of many research groups in developing effective remediation techniques for their detoxification.

Biodegradation of PAHs under aerobic or anaerobic conditions represents an interesting and eco-friendly alternative, ${ }^{3}$ however, both methodologies show some drawbacks. The anaerobic pathway is slow and information about the biochemical mechanism involved is scarce, whereas some of the oxidized intermediates formed in the aerobic biodegradation are more hydrophilic and, therefore, may have higher bioavailability and toxicity than the PAHs themselves.

\footnotetext{
* Corresponding author. Tel./fax: +54 291459 5187; e-mail address:gradivoy@ criba.edu.ar (G. Radivoy).
}

On the other hand, the reduction of PAHs can be achieved by different methods, mainly by catalytic hydrogenation ${ }^{4-6}$ or by the use of dissolving metals. ${ }^{7}$ These and other dearomatization reactions ${ }^{8}$ represent a very important and useful chemical transformation that provide both a method for the conversion of PAHs into less toxic compounds and/or into substructures of bioactive synthetic targets, especially in the reduction of polycyclic heteroaromatic hydrocarbons such as quinolines, isoquinolines and other aromatic $\mathrm{N}$-heterocycles. ${ }^{5,7 e}$ Moreover, some specific hydroaromatic compounds such as tetrahydronaphthalene, tetrahydroquinoline, and tetrahydronaphthol derivatives have found a wide range of important applications, not only in the pharmaceutical industry ${ }^{9}$ but also as high-temperature stabilizers for jet fuels. ${ }^{10}$ For most of the above mentioned hydrogenation reactions, the use of noble-metal catalysts is well known and has shown to be efficient in the reduction of different aromatic compounds. However, they often require the use of elevated temperatures or high hydrogen pressures in order to be active.

In recent years, the synthesis of transition-metal nanoparticles (NPs) and their application in catalysis has received considerable attention. ${ }^{11}$ However, few reports appear in the literature regarding the metal-NP-catalyzed hydrogenation of PAHs, ${ }^{6 b-d, 12}$ most of them referred to the use of noble-metal NPs stabilized by different supports or ligands. The unique catalytic properties of these metal NPs are considered to be strongly related to their high surface area and the

0040-4020/\$ - see front matter (c) 2010 Elsevier Ltd. All rights reserved. doi:10.1016/j.tet.2010.04.026 
possibility of charge distribution in electron transfer reactions, thus allowing the use of milder reaction conditions, i.e., lower temperatures and pressures, compared to those of the bulk metal catalysts.

In previous papers, we have reported our results on the preparation of transition-metal NPs (NiNPs, FeNPs, and CuNPs), which have been utilized for various important organic transformations in our laboratories, mainly for reduction and coupling reactions. We prepared the above mentioned transition-metal NPs under mild reaction conditions, in tetrahydrofuran as the solvent and at room temperature, from the corresponding commercially available metal (II) chlorides by reaction with lithium sand and a catalytic amount of an arene as electron carrier. This methodology allowed the obtention of very reactive, monodisperse spherical nickel(0), iron (0) or copper(0) nanoparticles with an average size near $3.0 \pm 1.5 \mathrm{~nm}$, which efficiently promoted a wide variety of useful organic synthetic transformations. ${ }^{13-15}$

Based on our previous results in the field, ${ }^{16}$ and prompted by our continuous interest in the search of new and useful synthetic applications of transition-metal NPs, ${ }^{13-15,17}$ we decided to explore the performance of CoNPs and MnNPs in the reduction of PAHs. We want to present herein our findings in the preparation of manganese and cobalt nanoparticles, in the absence of any anti-agglomeration additive or ligand, and their application to the reduction of different polycyclic aromatic and heteroaromatic hydrocarbons (Scheme 1). To the best of our knowledge, this is the first report describing the use of naked CoNPs or MnNPs for the reduction of PAHs.<smiles>[R]C1=CC=C2[Y]C(=C1)C=CC=C2[R]</smiles>

1

$$
\frac{\mathrm{CoCl}_{2} \cdot 6 \mathrm{H}_{2} \mathrm{O} \text { or } \mathrm{MnCl}_{2} \cdot 2 \mathrm{H}_{2} \mathrm{O}}{\mathrm{Li}, \mathrm{THF}, 25^{\circ} \mathrm{C}}
$$

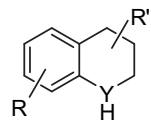

2

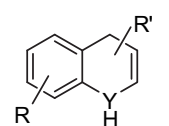

3
$\mathrm{R}=\mathrm{H}$, alkyl, $\mathrm{OH}, \mathrm{OCH}_{3}, \mathrm{NH}_{2}, \mathrm{Br}, \mathrm{F}$

$\mathrm{R}^{\prime}=\mathrm{H}$, condensed aromatic

$\mathrm{Y}=\mathrm{CH}, \mathrm{N}$

Scheme 1. CoNP- or MnNP-promoted reduction of PAHs.

\section{Results and discussion}

\subsection{Synthesis and characterization of CoNPs and MnNPs}

The cobalt or manganese nanoparticles were generated in situ by reduction of commercially available $\mathrm{CoCl}_{2} \cdot 6 \mathrm{H}_{2} \mathrm{O}$ or $\mathrm{MnCl}_{2} \cdot 2 \mathrm{H}_{2} \mathrm{O}$ with an excess of lithium sand (1:8 $\mathrm{M}$ ratio relative to the corresponding manganese or cobalt dichloride), tetrahydrofuran (THF) as the solvent, at room temperature under a nitrogen atmosphere. It is noteworthy that the PAH substrate itself was used as the electron carrier (see Experimental section for details). Typical transmission electron microscopy (TEM) micrographs and size distribution graphics for both CoNPs and MnNPs are shown in Figures 1 and 2, respectively. Highly monodisperse and spherical nanoparticles were observed with a size distribution range of ca. $3.5 \pm 1.5 \mathrm{~nm}$ for the CoNPs and 2.5 $\pm 1.5 \mathrm{~nm}$ for the MnNPs.
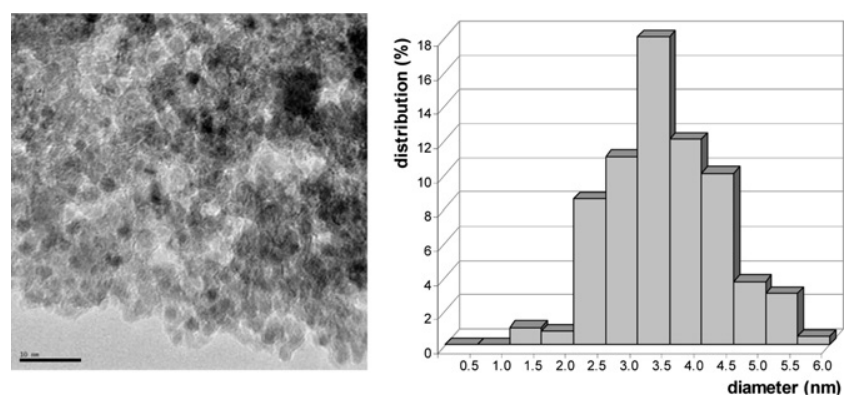

Figure 1. TEM micrograph and size distribution of the CoNPs. The sizes were determined for 150 nanoparticles selected at random.
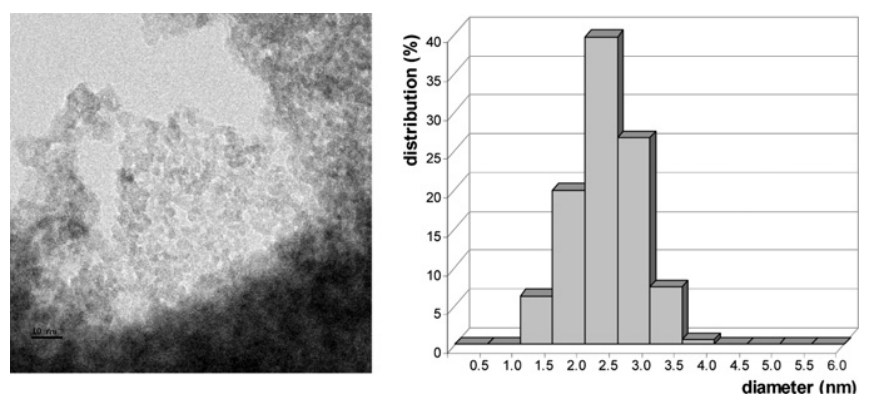

Figure 2. TEM micrograph and size distribution of the MnNPs. The sizes were determined for 150 nanoparticles selected at random.

Energy-dispersive X-ray analysis (EDX) on various regions confirmed the presence of cobalt or manganese, respectively, with energy bands of 6.9 and $7.7 \mathrm{keV}$ (K lines) for cobalt and of 5.9 and $6.5 \mathrm{keV}$ ( $\mathrm{K}$ lines) for manganese. The X-ray diffraction spectrum (XRD) of the MnNPs, showed peaks around $2 \theta$ of $34.9^{\circ}, 40.6^{\circ}$, and $58.9^{\circ}$, which could be attributed to $\mathrm{MnO}$. The presence of $\mathrm{MnO}$ in the sample could be due to the oxidation of MnNPs during sample manipulation in air before the analysis. The XRD analysis of the CoNPs did not show any significant peak, which could be due to the amorphous character of the sample and/or to the existence of crystal domains below $10 \mathrm{~nm}$ in size.

\subsection{Reduction of PAHs promoted by CoNPs or MnNPs}

As mentioned in the preceding section, the metal NPs were in situ generated by reduction of $\mathrm{CoCl}_{2} \cdot 6 \mathrm{H}_{2} \mathrm{O}$ or $\mathrm{MnCl}_{2} \cdot 2 \mathrm{H}_{2} \mathrm{O}(1.0 \mathrm{mmol})$ with an excess of lithium sand $(8.0 \mathrm{mmol})$ in the presence of the corresponding PAH $(1.0 \mathrm{mmol})$, which, in addition, was used as electron carrier. All reactions were performed in THF $(7 \mathrm{~mL})$ as the solvent and under a nitrogen atmosphere. Scheme 1 summarizes the reaction conditions and the reduction products observed in this work.

The results obtained in the reduction of unsubstituted aromatic and heteroaromatic polycyclic hydrocarbons promoted by CoNPs or MnNPs are shown in Table 1. Under the above conditions, the reaction of naphthalene (1a) with CoNPs quantitatively gave 1,2,3,4-tetrahydronaphthalene (2a) in $3 \mathrm{~h}$ at room temperature (Table 1, entry 1 ). The MnNPs showed to be less reactive with the same PAH substrate, an excess of the MnNPs (2.0 equiv relative to naphthalene) being necessary to give $2 \mathrm{a}$ in only $38 \%$ yield after $6.5 \mathrm{~h}$ (Table 1, entry 1 ). It is worthy of note that, in the latter case and at shorter reaction times (15-30 min), we detected the presence of 1,4-dihydronaphthalene as intermediate in the reaction medium, albeit $60 \%$ of the starting naphthalene was recovered at the final reaction time. The reaction with anthracene (1b) was quite different, both CoNPs and MnNPs demonstrating to have a similar reactivity to give 9,10-dihydroanthracene (2b) in $2 \mathrm{~h}$ and excellent yield (Table 1, entry 2 ). The reduction of phenanthrene (1c) with CoNPs or MnNPs showed a similar reactivity pattern to that of the reduction of naphthalene. Thus, the CoNPs demonstrated to be much more reactive than the MnNPs, rendering 9,10-dihydrophenanthrene (2c) in only $3 \mathrm{~h}$ (Table 1, entry 3 ), while also allowing the use of a substoichiometric amount of the CoNPs ( 0.5 equiv relative to the PAH substrate). In the case of chrysene (1d), a PAH reluctant to undergo hydrogenation, both CoNPs and MnNPs needed long reaction times to render 5,6-dihydrochrysene (2d) in moderate yields (Table 1, entry 4).

The use of $\mathrm{CoCl}_{2} \cdot 4 \mathrm{D}_{2} \mathrm{O}$ as a source of CoNPs (see Experimental section for details on its preparation) for the reduction of anthracene (1) allowed the formation of the corresponding dideuterated product ( $d_{2}-\mathbf{2 b}$ ), as expected, at the 9,10-positions (Table 1, entry 5). We next considered the reduction of nitrogen-containing polycyclic heteroaromatic hydrocarbons. In the case of quinoline (1e), the 
Table 1

Reduction of unsubstituted PAHs promoted by CoNPs or MnNPs ${ }^{\mathrm{a}}$

\begin{tabular}{|c|c|c|c|c|c|c|c|}
\hline \multirow[t]{2}{*}{ Entry } & \multirow[t]{2}{*}{ Starting PAH } & & \multicolumn{2}{|c|}{ Reaction time (h) } & \multirow[t]{2}{*}{ Product structure } & \multicolumn{2}{|c|}{ Yield $^{\mathrm{b}}(\%)$} \\
\hline & & & CoNPs & MnNPs & & CoNPs & MnNPs \\
\hline 1 & & (1a) & 3.0 & $6.5^{c}$ & $(\mathbf{2 a})$ & 98 & 38 \\
\hline 2 & & (1b) & 2.0 & 2.0 & $(2 b)$ & 87 & 91 \\
\hline 3 & & (1c) & $3.0^{\mathrm{d}}$ & 15.0 & $(2 c)$ & 73 & 27 \\
\hline 4 & & $(\mathbf{1 d})$ & 22.0 & $26.0^{c}$ & $(2 d)$ & 61 & 60 \\
\hline 5 & & (1b) & $3.5^{\mathrm{e}}$ & - & $d_{2}-(\mathbf{2 b})$ & $92^{\mathrm{f}}$ & - \\
\hline 6 & & (1e) & $4.0^{g}$ & $10.0^{\mathrm{g}}$ & $(2 e)$ & 90 & 0 \\
\hline 7 & & (1f) & 3.5 & $6.0^{c}$ & (2f) & 95 & 90 \\
\hline 8 & & (1g) & 6.0 & 8.0 & & 67 & 45 \\
\hline
\end{tabular}

${ }^{a}$ Reaction conditions: PAH (1.0 mmol), CoNPs or MnNPs (1.0 mmol), in THF as the solvent $(7 \mathrm{~mL})$, at $25^{\circ} \mathrm{C}$, unless otherwise stated.

${ }^{b}$ Isolated yield after column chromatography (hexane/EtOAc), based on the starting PAH.

c Reaction performed using 2.0 equiv of the MnNPs relative to the starting PAH.

d Reaction performed using 0.5 equiv. of the CoNPs relative to the starting PAH.

e $\mathrm{CoCl}_{2} \cdot 4 \mathrm{D}_{2} \mathrm{O}$ was used instead of $\mathrm{CoCl}_{2} \cdot 6 \mathrm{H}_{2} \mathrm{O}$.

${ }^{\mathrm{f}}$ Deuterium incorporation >95\% (MS, NMR). A 98:2 diastereomeric ratio was observed by GLC/EM analysis.

${ }^{g}$ Reaction performed at the reflux temperature of $\operatorname{THF}\left(66^{\circ} \mathrm{C}\right)$.

reduction could only be accomplished by the CoNPs and at the reflux temperature of THF (Table 1, entry 6). The hydrogenation of this heteroaromatic substrate took place on the nitrogenated ring to give 1,2,3,4-tetrahydroquinoline (2e) in $90 \%$ yield. On the other hand, the reduction of 1,10-phenanthroline (1f) was efficiently promoted by both the Co- and MnNPs leading to the obtention of 1,2,3,4-tetrahydro-1,10-phenanthroline (2f) in excellent yields (Table 1, entry 7), although it was necessary to use an excess of the MnNPs (2.0 equiv relative to the $\mathrm{PAH}$ substrate). Taking into account the importance of the substituted indoles for the synthesis of bioactive compounds, we applied our methodology for the reduction of 2-(2-naphthyl)indole (1g). In this case, the reduction took place at the naphthyl ring directly attached to the indole moiety with both the CoNPs and MnNPs, giving the corresponding tetrahydro derivative $\mathbf{2} \mathbf{g}$ in moderate yield (Table 1 , entry 8 ).

In the second part of this study, we considered the reduction of substituted PAHs. Since both the CoNPs or the MnNPs failed to promote the reduction of naphthalene derivatives bearing electronwithdrawing groups (i.e., carbonyl, nitro, or carboxy group) or those substituted at the 2-position, ${ }^{18}$ we studied the reduction of 1 -substituted naphthalenes bearing electron-donating groups. Halogen atoms were an exception with regard to the mentioned electronic properties of the substituents, but in this case a hydrodehalogenation step prior to the aromatic ring reduction 
could be expected. ${ }^{19}$ The results obtained, which are summarized in Table 2, showed significant differences depending on the nature of the metal-NPs used. Thus, with the CoNPs-based reducing system, literature, ${ }^{21}$ once the arene radical anion is formed, two competitive reductive cleavage processes could take place, i.e., the rupture of the alkyl-oxygen bond (dealkylation reaction) or the rupture of the

Table 2

Reduction of substituted PAHs promoted by CoNPs or MnNPs ${ }^{\mathrm{a}}$

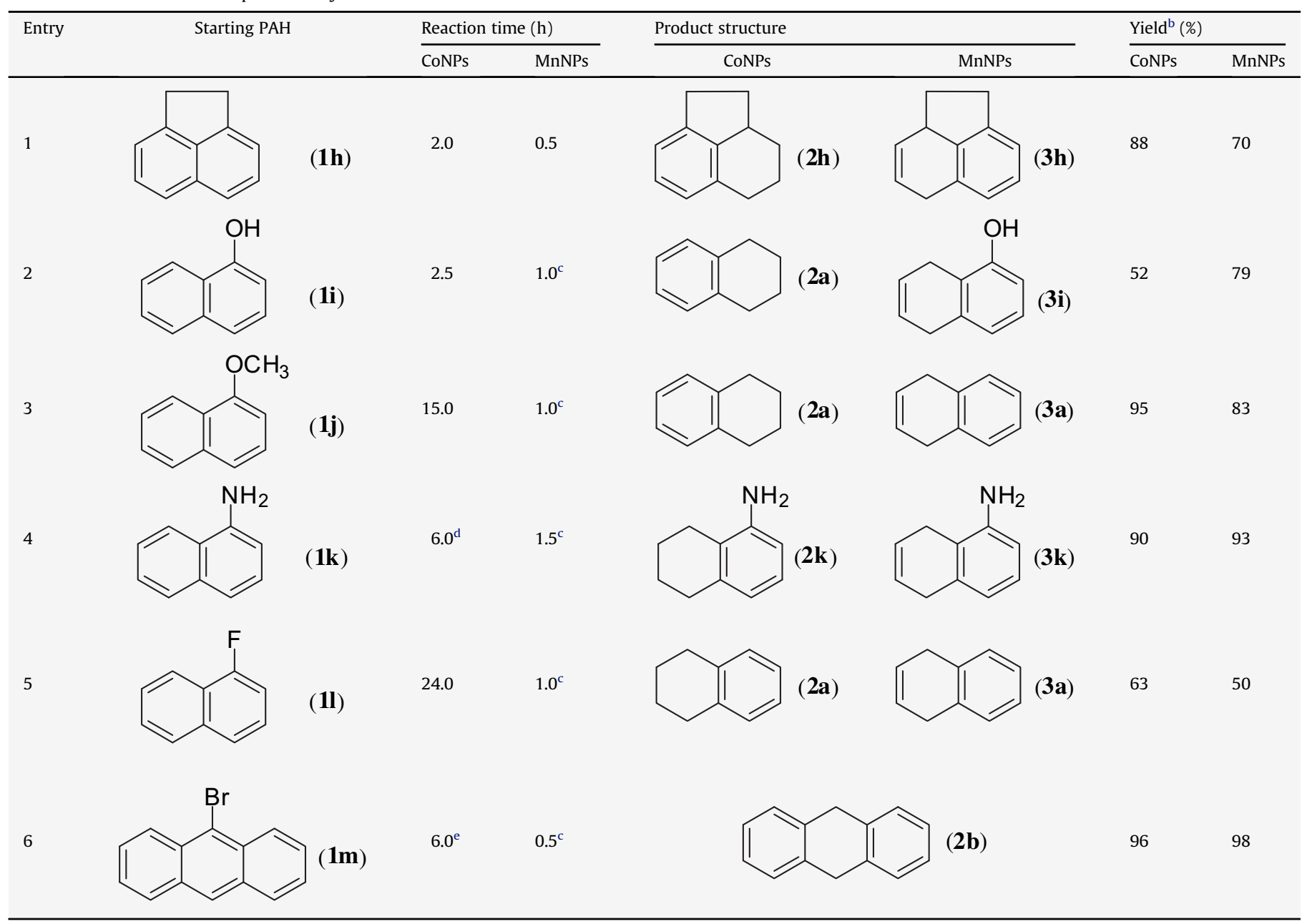

\footnotetext{
a Reaction conditions: PAH $(1.0 \mathrm{mmol})$, CoNPs or MnNPs $(1.0 \mathrm{mmol})$, in THF as solvent $(7 \mathrm{~mL})$, at $25^{\circ} \mathrm{C}$, unless otherwise stated

b Isolated yield after column chromatography (hexane/EtOAc), based on the starting PAH.

c Reaction performed using 2.0 equiv of the MnNPs, relative to the starting PAH.

d Reaction performed at the reflux temperature of THF $\left(66^{\circ} \mathrm{C}\right)$.

e Reaction performed using 0.5 equiv of the CoNPs, relative to the starting PAH.
}

the reduction of 1 -substituted naphthalenes $(\mathbf{1 h}-\mathbf{l})$ rendered the corresponding tetraline derivatives in moderate to excellent yields (Table 2, entries 1-4). These products are common intermediate compounds in most of the classical catalytic hydrogenation reactions of naphthalene derivatives over supported noble-metal catalysts. This resemblance with the catalytic hydrogenation reactions is also evidenced in the case of the reduction of 1-substituted naphthalenes bearing oxygenated functionalities, such as 1-naphthol (1i) and 1-methoxynaphthalene (1j) (Table 2, entries 2 and 3, respectively), where it is well known that the reduction of the aromatic ring of naphthols or phenols is accompanied by the hydrogenolysis of the $\mathrm{C}-\mathrm{O}$ bond. ${ }^{10,20}$ With substrates $\mathbf{1 i}$ and $\mathbf{1 j}$, the reduction took place at the substituted naphthyl ring, since we could observe a mixture of dihydro 1-naphthalenol isomers by analyzing sample aliquots of the reaction mixture at short reaction times. In the case of 1-methoxynaphthalene $(\mathbf{1 j} \mathbf{j})$, the reductive cleavage of the ether functionality, which could occur prior to the hydrogenation of the aromatic ring, is not so unexpected under the reaction conditions. According to the aryl-oxygen bond (dearylation reaction). As shown in Scheme 2, dearylation (path $\mathbf{a}$ ) or dealkylation (path $\mathbf{b}$ ) of $\mathbf{1 j}$ could lead, after protonation of the corresponding anion intermediates, to the formation of naphthalene or 1-naphthol, respectively, which would then be hydrogenated to tetraline (2a) under the reaction conditions. On the other hand, the CoNP-mediated reduction of 1-naphthylamine (1k) took place at the unsubstituted naphthyl ring (Table 2, entry 4 ), and no hydrogenolysis of the $\mathrm{C}-\mathrm{N}$ bond was observed for this substrate.

As mentioned above, the reduction of the aromatic ring of halosubstituted PAHs was accompanied by the hydrodehalogenation of the substrate. ${ }^{19}$ Thus, 1 -fluoronaphthalene (11) was reduced to 1,2,3,4-tetrahydronaphthalene (2a) in moderate yield (Table 2, entry 5), and 9-bromoanthracene (1m) was almost quantitatively converted into 9,10-dihydroanthracene (2b) (Table 2, entry 6). The hydrodefluorination of 1-fluoronaphthalene is noteworthy since due to the strength of the carbon-fluorine bond, fluorides are rather resistant to reduction. Many efforts have been devoted to 
overcome their chemical inertness by appropriate activation. ${ }^{22}$ The hydrodefluorination of aryl fluorides was previously reported by us to occur under the promotion of active iron. ${ }^{14 \mathrm{~b}}$ Nevertheless, it is known that the arene-catalyzed lithiation of alkyl or aryl fluorides can lead to the corresponding alkyl- or aryl-lithium compounds. ${ }^{23}$ We confirmed that a fluorine/lithium exchange could proceed under our reaction conditions, by performing the reaction of 1-fluoronaphthalene (11) with an excess of lithium in the absence of the CoNPs. Thus, after stirring overnight, naphthalene was obtained as the major reaction product $(90 \%)$ together with a mixture of dihydronaphthalene isomers (7\%) and binaphthyl (3\%). hydrogen formed by reaction of the excess of lithium with the metalsalt hydration water to the aromatic ring, or (ii) a dissolving-metaltype reaction involving the metal-NPs and a proton source (water). A series of experiments were carried out with 1-naphthol as the test compound in order to gain an insight into the plausible reaction mechanism involved for both the CoNP- and the MnNP-promoted $\mathrm{PAH}$ reductions. Experiment A: the reaction of 1-naphthol (1i) with the CoNPs generated from anhydrous $\mathrm{CoCl}_{2}$ under a $\mathrm{H}_{2}$ atmosphere gave 1,2,3,4-tetrahydro-1-naphthalenol (30\%), tetraline (23\%) and unreacted starting material (43\%). Experiment B: the reaction of 1-naphthol (1i) with the CoNPs generated from anhydrous $\mathrm{CoCl}_{2}$

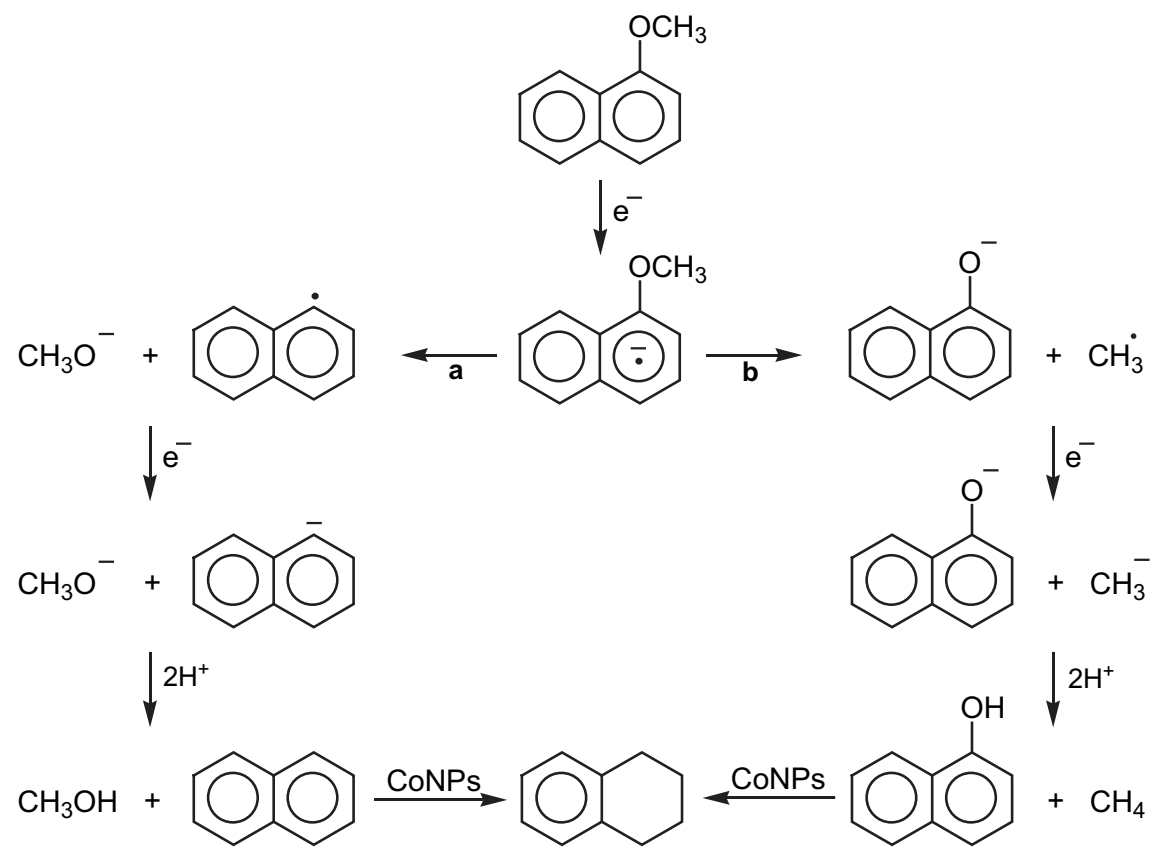

Scheme 2. Possible reaction pathways in the CoNP-promoted reduction of 1-methoxynaphthalene.

On the other hand, the reduction products of 1-substituted naphthalenes with the MnNP-based reducing system were more consistent with a dissolving-metal-type reaction. As shown in Table 2 (entries 1-4), the corresponding non-conjugated 1,4 - or 5,8 dihydro naphthalene derivatives (3) were the main reaction products, the reduction taking place at the unsubstituted naphthyl ring and at a higher rate than that of the CoNP-promoted reductions. It was necessary, however, to use an excess of the MnNPs (2.0 equiv relative to the $\mathrm{PAH}$ substrate) in order to improve the reaction yields. The reduction of 1 -methoxynaphthalene $(\mathbf{1 j})$ led to the corresponding demethoxylated 5,8-dihydro derivative 3a. The observed $\mathrm{C}-\mathrm{O}$ bond cleavage, which would proceed as described above (Scheme 2, path a), could not be overcome neither by shortening the reaction time nor by lowering the reaction temperature $\left(-50^{\circ} \mathrm{C}\right)$. The reduction of 1 -fluoronaphthalene (11) with the MnNPs-based reducing system led to the corresponding hydrodehalogenated 1,4-dihydro derivative 3a in moderate yield and naphthalene as a byproduct (Table 2, entry 5 ). Here again, hydrodefluorination of the starting material would occur as described above for the CoNP-promoted reduction of 11. Finally, the reduction of 9-bromoanthracene (1m) gave 9,10-dihydroanthracene (2b) after only $30 \mathrm{~min}$ of reaction and in excellent yield (Table 2, entry 6).

Although the mechanism involved in the above reactions is difficult to ascertain at this point, two pathways could be involved, on the basis of the results obtained in this study: (i) a catalytic hydrogenation-type reaction, where the metal-NPs could transfer the under a $\mathrm{N}_{2}$ atmosphere rendered, after aqueous workup, 1,2,3,4-tetrahydro-1-naphthalenol (42\%), a mixture of dihydro naphthalenol isomers (15\%) and unreacted starting material (38\%). Experiment C: the reaction of 1-naphthol (1i) with the MnNPs generated from anhydrous $\mathrm{MnCl}_{2}$ under a $\mathrm{H}_{2}$ atmosphere, furnished 5,8-dihydro-1naphthol (15\%) and unreacted starting material (60\%). Experiment D: the reaction of 1-naphthol (1i) with the MnNPs generated from anhydrous $\mathrm{MnCl}_{2}$ under a $\mathrm{N}_{2}$ atmosphere furnished, after aqueous workup, 5,8-dihydro-1-naphthol (60\%) and unreacted starting material (33\%)

From the results obtained in the above described experiments, it could be inferred that both the CoNP- and the MnNP-promoted reductions could proceed mainly through a dissolving metal-type mechanism, nevertheless, in the case of the CoNP-based reducing system, a catalytic hydrogenation-type reaction could also occur to some extent. By comparing experiments $\mathrm{A}$ and $\mathrm{B}$, it can be observed that hydrogenolysis of the $\mathrm{C}-\mathrm{O}$ bond of 1 -naphthol only takes place with the CoNPs in the presence of molecular hydrogen. On the other hand, the 5,8-dihydronaphthol obtained in experiment $C$ could be formed mainly through a dissolving metal-type reduction followed by proton abstraction by the intermediate from the solvent. This could also be inferred from the higher conversion obtained after aqueous workup in experiment D. Finally, it can also be concluded that the hydration water in both cobalt or manganese salts used, is the main hydrogen/proton source in the reduction reactions, being indispensable to obtain the reduced products in good yield. 


\section{Conclusions}

In summary, we have described herein a new and simple methodology for the partial reduction of polycyclic aromatic hydrocarbons based on the use of cobalt or manganese nanoparticles, generated in a simple and economic way by reduction of commercially available $\mathrm{CoCl}_{2} \cdot 6 \mathrm{H}_{2} \mathrm{O}$ or $\mathrm{MnCl}_{2} \cdot 2 \mathrm{H}_{2} \mathrm{O}$ in the presence of lithium sand and the corresponding $\mathrm{PAH}$, the latter also acting as an electron carrier. Both reducing systems have demonstrated to be efficient in the partial reduction of polycyclic aromatic and heteroaromatic hydrocarbons under mild reaction conditions. The regiochemistry and degree of reduction with 1-substituted naphthalene derivatives markedly depends on the nature of the metal-NPs used, the CoNP-promoted reduction leading to the corresponding tetraline products, whereas the MnNPs allowed the formation of the unconjugated 5,8-dihydro derivatives. Taking into account the synthetic and industrial importance of partially hydrogenated aromatics and heteroaromatics for the preparation of the corresponding benzo fused compounds, the new methodology presented in this paper can be considered as an attractive alternative to other well known reduction methods such as the Birch reaction or the classical catalytic hydrogenation.

\section{Experimental}

\subsection{General}

All moisture sensitive reactions were carried out under a nitrogen atmosphere. Anhydrous tetrahydrofuran was freshly distilled from sodium/benzophenone ketyl. Other solvents used were treated prior to use by standard methods. ${ }^{24}$ All starting materials were of the best available grade (Aldrich, Merck) and were used without further purification. Commercially available $\mathrm{CoCl}_{2} \cdot 6 \mathrm{H}_{2} \mathrm{O}$ and $\mathrm{MnCl}_{2} \cdot 2 \mathrm{H}_{2} \mathrm{O}$ were used for the reduction reactions. $\mathrm{CoCl}_{2} \cdot 4 \mathrm{D}_{2} \mathrm{O}$ for deuteration reactions was prepared by treating anhydrous $\mathrm{CoCl}_{2}$ with an excess of $\mathrm{D}_{2} \mathrm{O}$ and then by heating in vacuo (ca. 0.5 Torr) at $60{ }^{\circ} \mathrm{C}$ during $2 \mathrm{~h}$. Column chromatography was performed with Merck silica gel $60(0.040-0.063 \mu \mathrm{m}$, 240-400 mesh). Thin layer chromatography (TLC) was performed on precoated silica gel plates (Merck 60, F $254,0.25 \mathrm{~mm}$ ). 2-(2Naphthyl)indole (Table 1 , entry 8 ) was prepared according to the literature. ${ }^{25}$ All other starting PAHs were purchased form commercial sources (Aldrich), and used as received.

\subsection{Instrumentation and analysis}

Nuclear magnetic resonance (NMR) spectra were recorded on a Bruker ARX-300 spectrophotometer using $\mathrm{CDCl}_{3}$ (unless otherwise stated) as solvent and tetramethylsilane (TMS) as internal reference. Mass spectra (EI) were obtained at $70 \mathrm{eV}$ on a Hewlett Packard HP-5890 GC/MS instrument equipped with a HP-5972 selective mass detector. The purity of volatile compounds and the chromatographic analyses (GC) were determined with a Shimadzu GC-9A instrument equipped with a flame-ionization detector and a $2 \mathrm{~m}$ column (1.5\% OV17 9 A SUS Chrom 103 80/ $1000)$, using nitrogen as carrier gas. TEM images of cobalt and manganese nanoparticles were recorded at the TEM service of the University of Alicante (Spain) using a Jeol JEM2010 microscope equipped with a lanthanum hexaboride filament and operated at an acceleration voltage of $200 \mathrm{kV}$. X-ray diffraction (XRD) analyses were performed at the XRD service of the INGEOSUR (UNS-CONICET, Argentina) using a Rigaku Geigerflex $\mathrm{D} \max$ III $\mathrm{C}$ equipment: $\mathrm{Cu} \mathrm{K} \alpha_{1}$ irradiation, $\lambda=1.5406 ; 25^{\circ} \mathrm{C}$; $2 \theta=3-90$.

\subsection{Synthesis of 2-(2-naphthyl)indole $(1 \mathrm{~g})^{25}$}

A mixture of phenylhydrazine ( $1.45 \mathrm{~mL}, 1.62 \mathrm{~g}, 15.0 \mathrm{mmol}$ ) and 2acetylnaphthalene $(2.55 \mathrm{~g}, 15.0 \mathrm{mmol})$ was added to polyphosphoric acid $(45.0 \mathrm{~g}$ ) in a two-necked round-bottom flask under a nitrogen atmosphere. The viscous mass was mixed thoroughly under a nitrogen stream and kept at $100{ }^{\circ} \mathrm{C}$. The reaction mixture was stirred every few minutes and stopped as soon as a deep yellow color was observed. Then, the reaction mixture was poured into ice water $(150 \mathrm{~mL})$ and the product separated was collected by filtration. Recrystallization (benzene) of the crude product gave pure 2-(2-naphthyl)indole ( $3.5 \mathrm{~g}, 66 \%$ ) as a brown-yellow solid; $\mathrm{mp} 163-165{ }^{\circ} \mathrm{C}$; IR (KBr) 3360, 3020-3060, 1605, 1570, 1150, $1080 \mathrm{~cm}^{-1}$; ${ }^{1} \mathrm{H}$ NMR $\left(300 \mathrm{MHz} \mathrm{CDCl}_{3}\right) \delta 6.84-6.86$ (br s, $\left.1 \mathrm{H}, \mathrm{CH}_{\text {indole }}\right), 7.06(\mathrm{t}, J=8.0 \mathrm{~Hz}, 1 \mathrm{H}$, $\left.\mathrm{CH}_{\text {naphthyl }}\right), 7.12\left(\mathrm{t}, J=8.2 \mathrm{~Hz}, 1 \mathrm{H}, \mathrm{CH}_{\text {naphthyl }}\right), 7.32(\mathrm{~d}, J=7.9 \mathrm{~Hz}, 1 \mathrm{H}$, $\left.\mathrm{CH}_{\text {naphthyl }}\right), \quad 7.34-7.44\left(\mathrm{~m}, 2 \mathrm{H}, \mathrm{CH}_{\text {indole }}\right.$ and $\left.\mathrm{CH}_{\text {naphthyl }}\right), \quad 7.56$ (d, $\left.J=7.6 \mathrm{~Hz}, 1 \mathrm{H}, \mathrm{CH}_{\text {naphthyl }}\right), 7.68-7.82\left(\mathrm{~m}, 4 \mathrm{H}, 3 \times \mathrm{CH}_{\text {indole }}\right.$ and $\mathrm{CH}_{\text {naphthyl }}$ ), 7.93 (br s, $1 \mathrm{H}, \mathrm{CH}_{\text {naphthyl }}$ ), 8.31 (br s, $1 \mathrm{H}, \mathrm{NH}$ ); ${ }^{13} \mathrm{C}$ NMR $\left(75 \mathrm{MHz}, \mathrm{CDCl}_{3}\right) \delta 100.7,110.9,120.4,120.7,122.6,123.1,123.8,126.1$, $126.7,127.8,128.0,128.8,129.4,129.7,132.9,133.6,137.1,137.9$.

\subsection{Representative procedure for the reduction of PAHs promoted by CoNPs or MnNPs}

The corresponding pure PAH substrate $(1.0 \mathrm{mmol})$ was added to a vigorously stirred suspension of lithium sand $(56 \mathrm{mg}, 8.0 \mathrm{mmol}$ ) and cobalt(II) chloride hexahydrate $(238 \mathrm{mg}, 1.0 \mathrm{mmol})$ or manganese(II) chloride dihydrate (162 mg, $1.0 \mathrm{mmol}$ ) in THF ( $7 \mathrm{~mL}$ ), under a nitrogen atmosphere. The reaction mixture turned black indicating that the metal nanoparticles were formed. The reaction progress was monitored by TLC and GLC/MS. The resulting suspension was diluted with ether $(10 \mathrm{~mL})$ and filtered through a pad containing Celite. The filtrate was evaporated ( 15 Torr) and the resulting residue purified by flash column chromatography (silica gel, hexane/EtOAc) to afford the corresponding reduced PAH. For known compounds $2 \mathbf{a}^{26}{ }^{26} \mathbf{2 b}^{27}$ $\mathbf{2 c},{ }^{27} \mathbf{2 d},{ }^{28} d_{2}-\mathbf{2 b},{ }^{29} \mathbf{2 e},{ }^{30} \mathbf{2 f},{ }^{30} \mathbf{2 h},{ }^{31} \mathbf{2 k},{ }^{32} \mathbf{3 h},{ }^{33} \mathbf{3 i},{ }^{34} \mathbf{3 a},{ }^{35}$ and $\mathbf{3 k},{ }^{36}$ partially described in the literature, as well as for unknown compound $\mathbf{2 g}$, physical and spectroscopic data follow.

4.4.1. 1,2,3,4-Tetrahydronaphthalene $(\mathbf{2 a})^{26}$. Colorless oil; IR (film) $3090,3060,2930,2870,1500,1450,1430,747 \mathrm{~cm}^{-1} ;{ }^{1} \mathrm{H}$ NMR $\left(300 \mathrm{MHz}^{\mathrm{CDCl}} 3\right) \delta 1.75-1.77\left(\mathrm{~m}, 4 \mathrm{H}, 2 \times \mathrm{CH}_{2}\right), 2.72-2.74(\mathrm{~m}, 4 \mathrm{H}$, $\left.2 \times \mathrm{CH}_{2}\right), 7.00-7.04(\mathrm{~m}, 4 \mathrm{H}, 4 \times \mathrm{CH}) ;{ }^{13} \mathrm{C} \mathrm{NMR}\left(75 \mathrm{MHz}, \mathrm{CDCl}_{3}\right) \delta 23.2$, 29.3, 125.3, 129.0, 137.0; MS-EI (m/z): 132 ( $\left.\mathrm{M}^{+}, 56 \%\right), 117$ (15), 115 (12), 105 (10), 104 (100), 91 (43), 77 (13), 65 (13), 51 (17), 39 (17) HRMS-EI $(\mathrm{m} / \mathrm{z})$ : $[\mathrm{M}]^{+}$calcd for $\mathrm{C}_{10} \mathrm{H}_{12}, 132.0939$; found 132.0941 .

4.4.2. 9,10-Dihydroanthracene $(\mathbf{2 b})^{27}$. Brown solid, $\mathrm{mp} 108-110{ }^{\circ} \mathrm{C}$; IR (KBr) 3030, 3020, 2980, 2940, 2880, 1490, 1450, 760, 745, $730 \mathrm{~cm}^{-1}$; ${ }^{1} \mathrm{H}$ NMR $\left(300 \mathrm{MHz}, \mathrm{CDCl}_{3}\right) \delta 3.74\left(\mathrm{~s}, 4 \mathrm{H}, 2 \times \mathrm{CH}_{2}\right)$, 7.00-7.04 (m, $4 \mathrm{H}, 4 \times \mathrm{CH}), 7.08-7.12(\mathrm{~m}, 4 \mathrm{H}, 4 \times \mathrm{CH}) ;{ }^{13} \mathrm{C} \mathrm{NMR}$ $\left(75 \mathrm{MHz}, \mathrm{CDCl}_{3}\right) \delta 36.0,125.9,127.3,136.5$; MS-EI $(\mathrm{m} / \mathrm{z}): 180\left(\mathrm{M}^{+}\right.$, 100\%), 179 (95), 178 (51), 165 (20), 89 (21), 76 (13). HRMS-EI $(\mathrm{m} / z)$ : $[\mathrm{M}]^{+}$calcd for $\mathrm{C}_{14} \mathrm{H}_{12}, 180.0939$; found 180.0941 .

4.4.3. 9,10-Dihydrophenanthrene (2c $)^{27}$. Yellow solid, $\mathrm{mp}$ 32-35 ${ }^{\circ} \mathrm{C}$; IR (film) 3102, 3066, 2937, 2836, 1494, 1488, 1464, 772, $745,726 \mathrm{~cm}^{-1} ;{ }^{1} \mathrm{H}$ NMR (300 MHz, $\left.\mathrm{CDCl}_{3}\right) \delta 2.87\left(\mathrm{~s}, 4 \mathrm{H}, 2 \times \mathrm{CH}_{2}\right)$, $7.20-7.22(\mathrm{~m}, 2 \mathrm{H}, 2 \times \mathrm{CH}), 7.22-7.24(\mathrm{~m}, 2 \mathrm{H}, 2 \times \mathrm{CH}), 7.28-7.30(\mathrm{~m}$, $2 \mathrm{H}, 2 \times \mathrm{CH}), 7.73-7.76(\mathrm{~m}, 2 \mathrm{H}, 2 \times \mathrm{CH}) ;{ }^{13} \mathrm{C} \mathrm{NMR}\left(75 \mathrm{MHz}, \mathrm{CDCl}_{3}\right)$ $\delta 28.9,123.6,126.8,127.2,128.0,134.4,137.2$; MS-EI $(m / z): 180\left(\mathrm{M}^{+}\right.$, 100\%), 179 (61), 178 (36), 165 (26), 89 (15), 76 (11). HRMS-EI $(m / z)$ : $[\mathrm{M}]^{+}$calcd for $\mathrm{C}_{14} \mathrm{H}_{12}, 180.0939$; found 180.0936 .

4.4.4. 5,6-Dihydrochrysene (2d $)^{28}$. White solid, mp $204-207^{\circ} \mathrm{C}$; IR (KBr) 3054, 3034, 3019, 2956, 2937, 2883, 2832, 1489, 816, 761, 
$734 \mathrm{~cm}^{-1}$; ${ }^{1} \mathrm{H}$ NMR $\left(300 \mathrm{MHz}, \mathrm{CDCl}_{3}\right) \delta 2.88\left(\mathrm{t}, J=7.3 \mathrm{~Hz}, 2 \mathrm{H}, \mathrm{CH}_{2}\right)$, $3.19\left(\mathrm{t}, J=7.3 \mathrm{~Hz}, 2 \mathrm{H}, \mathrm{CH}_{2}\right), 7.11-7.26(\mathrm{~m}, 3 \mathrm{H}, 3 \times \mathrm{CH}), 7.32-7.44(\mathrm{~m}$, $2 \mathrm{H}, 2 \times \mathrm{CH}), 7.68-7.90(\mathrm{~m}, 4 \mathrm{H}, 4 \times \mathrm{CH}), 8.02(\mathrm{~d}, J=7.7 \mathrm{~Hz}, 1 \mathrm{H}) ;{ }^{13} \mathrm{C}$ $\operatorname{NMR}\left(75 \mathrm{MHz}, \mathrm{CDCl}_{3}\right) \delta 23.8,28.6,122.3,123.7,124.1,125.4,126.1$, 127.0, 127.3, 127.8, 128.5, 131.4, 131.7, 132.8, 133.1, 135.0, 136.9; MS-EI (m/z): $230\left(\mathrm{M}^{+}, 100 \%\right), 229$ (76), 228 (42), 227 (14), 226 (23), 215 (23), 202 (14), 114 (11). HRMS-EI $(m / z)$ : $[\mathrm{M}]^{+}$calcd for $\mathrm{C}_{18} \mathrm{H}_{14}$, 230.1096; found 230.1098 .

4.4.5. 9,10-Dideuterio-9,10-dihydroanthracene $\left(d_{2}-\mathbf{2 b}\right)^{29}$. White solid, mp 69-72 ${ }^{\circ} \mathrm{C}$; IR (KBr) 3058, 3027, 2953, 2925, 2828, 1474, 1450, 746, 726, $715 \mathrm{~cm}^{-1}$; ${ }^{1} \mathrm{H}$ NMR $\left(300 \mathrm{MHz}, \mathrm{CDCl}_{3}\right) \delta 3.93-3.95(\mathrm{~m}, 2 \mathrm{H}$, $2 \times \mathrm{CDH}), 7.18-7.22(\mathrm{~m}, 4 \mathrm{H}, 4 \times \mathrm{CH}), 7.27-7.31(\mathrm{~m}, 4 \mathrm{H}, 4 \times \mathrm{CH}) ;{ }^{13} \mathrm{C}$ NMR (75 MHz, $\left.\mathrm{CDCl}_{3}\right) \delta 35.7\left(\mathrm{t}, J_{\mathrm{C}-\mathrm{D}}=19.5 \mathrm{~Hz}, 2 \times \mathrm{CD}\right), 126.0,127.3$, 136.6; MS-EI (m/z): $182\left(\mathrm{M}^{+}, 100 \%\right), 181$ (90), 180 (55), 179 (26), 178 (14), 167 (23), 166 (13), 154 (16), 153 (19), 90 (17), 77 (14), 76 (12), 63 (15), 51 (11). HRMS-EI $(m / z)$ : [M] $]^{+}$calcd for $\mathrm{C}_{14} \mathrm{H}_{10} \mathrm{D}_{2}, 182.1065$; found 182.1069.

4.4.6. 1,2,3,4-Tetrahydroquinoline $(2 \boldsymbol{e})^{30}$. Pale yellow oil; IR (film) 3407, 3053, 3016, 2928, 2867, 1607, 1505, 1311, $747 \mathrm{~cm}^{-1} ;{ }^{1} \mathrm{H}$ NMR $\left(300 \mathrm{MHz}, \mathrm{CDCl}_{3}\right) \delta 1.92\left(\mathrm{q}, J=8.0 \mathrm{~Hz}, 2 \mathrm{H}, \mathrm{CH}_{2}\right), 2.72(\mathrm{t}, J=8.0 \mathrm{~Hz}, 2 \mathrm{H}$, $\left.\mathrm{CH}_{2}\right), 3.25\left(\mathrm{t}, J=8.0 \mathrm{~Hz}, 2 \mathrm{H}, \mathrm{CH}_{2}\right), 3.62(\mathrm{~s}, 1 \mathrm{H}, \mathrm{NH}), 6.35-7.10(\mathrm{~m}, 4 \mathrm{H}$, $4 \times \mathrm{CH}) ;{ }^{13} \mathrm{C}$ NMR $\left(75 \mathrm{MHz}, \mathrm{CDCl}_{3}\right) \delta 22.1,26.9,41.9,114.4,116.9$, 121.4, 126.6, 129.4, 144.7; MS-EI ( $m / z)$ : 133 ( $\left.\mathrm{M}^{+}, 84 \%\right), 132$ (100), 130 (12), 118 (21), 117 (18), 105 (35), 104 (13), 51 (10), 39 (12). HRMS-EI $(\mathrm{m} / \mathrm{z})$ : $[\mathrm{M}]^{+}$calcd for $\mathrm{C}_{9} \mathrm{H}_{11} \mathrm{~N}, 133.0891$; found 133.0883 .

4.4.7. 1,2,3,4-Tetrahydro-1,10-phenanthroline $(\mathbf{2 f})^{30}$. Pale yellow oil; IR (film) 3410, 3045, 2930, 2780, 1617, 1540, 1468, 1210, $940 \mathrm{~cm}^{-1}$. ${ }^{1} \mathrm{H}$ NMR $\left(300 \mathrm{MHz}, \mathrm{CDCl}_{3}\right) \delta 1.88-2.08\left(\mathrm{~m}, 2 \mathrm{H}, \mathrm{CH}_{2}\right), 2.82(\mathrm{t}$, $\left.J=6.0 \mathrm{~Hz}, 2 \mathrm{H}, \mathrm{CH}_{2}\right), 3.41-3.45\left(\mathrm{~m}, 2 \mathrm{H}, \mathrm{CH}_{2}\right), 5.85$ (br s, $\left.1 \mathrm{H}, \mathrm{NH}\right), 6.87$ $(\mathrm{d}, J=8.1 \mathrm{~Hz}, 1 \mathrm{H}, \mathrm{CH}), 7.05(\mathrm{~d}, J=8.0 \mathrm{~Hz}, 1 \mathrm{H}, \mathrm{CH}), 7.15-7.20(\mathrm{~m}, 1 \mathrm{H}$, $\mathrm{CH}), 7.89(\mathrm{~d}, J=8.0 \mathrm{~Hz}, 1 \mathrm{H}, \mathrm{CH}), 8.57-8.60(\mathrm{~m}, 1 \mathrm{H}, \mathrm{CH}) ;{ }^{13} \mathrm{C} \mathrm{NMR}$ $\left(75 \mathrm{MHz}, \mathrm{CDCl}_{3}\right) \delta 26.8,30.2,47.0,113.4,116.4,121.2,125.5,127.8$, 136.0,136.8, 139.9, 155.8; MS-EI $(\mathrm{m} / \mathrm{z}): 184\left(\mathrm{M}^{+}, 80 \%\right), 183(100), 181$ (14), 169 (22), 168 (14), $156(24), 155$ (15), $154(14), 129(17), 128(16)$. HRMS-EI $(m / z)$ : $[\mathrm{M}]^{+}$calcd for $\mathrm{C}_{12} \mathrm{H}_{12} \mathrm{~N}_{2}, 184.1000$; found 184.0994 .

4.4.8. 2-(1,2,3,4-Tetrahydro-2-naphthalenyl)-1H-indole (2g). Reddish-brown semi-solid; IR (film) 3409, 3076, 2963, 2920, 1642, 1619, 1262, $1095,796 \mathrm{~cm}^{-1} ;{ }^{1} \mathrm{H}$ NMR $\left(300 \mathrm{MHz}, \mathrm{CDCl}_{3}\right)$ $\delta$ 2.29-237 (m, $\left.2 \mathrm{H}, \mathrm{CH}_{2}\right), 2.93-2.99\left(\mathrm{~m}, 3 \mathrm{H}, \mathrm{Ar}-\mathrm{CH}_{2}\right.$ and $\left.\mathrm{CH}\right)$, 3.43-3.45 ( $\left.\mathrm{m}, 2 \mathrm{H}, \mathrm{Ar}-\mathrm{CH}_{2}\right), 6.31$ (br s, $\left.1 \mathrm{H}, \mathrm{CH}_{\text {indole }}\right), 7.09-7.21(\mathrm{~m}$, $8 \mathrm{H}, \mathrm{Ar}-\mathrm{CH}$ ), 7.55 (br s, $1 \mathrm{H}, \mathrm{NH}) ;{ }^{13} \mathrm{C}$ NMR $\left(75 \mathrm{MHz} \mathrm{CDCl}_{3}\right) \delta 28.8$, 29.3, 33.8, 35.5, 98.1, 110.4, 119.6, 119.9, 121.1, 125.7, 125.9, 128.5, 128.9, 129.0, 135.5, 135.7, 136.0, 143.5; MS-EI $(\mathrm{m} / \mathrm{z}): 247\left(\mathrm{M}^{+}\right.$, 80\%), 246 (15), 232 (23), 218 (21), 217 (14), 143 (100), 131 (50), 130 (77), 129 (23), 128 (19), 118 (21), 117 (79), 116 (14), 115 (42), 104 (22), 103 (19), 89 (21), 78 (20), 77 (20). HRMS-EI (m/z): [M] ${ }^{+}$calcd for $\mathrm{C}_{18} \mathrm{H}_{17} \mathrm{~N}, 247.1361$; found 247.1358 .

4.4.9. 1,2,2a,3,4,5-Hexahydroacenaphthylene $(\mathbf{2 h})^{31}$. Pale yellow oil; IR (film) 3039, 3021, 2926, 2866, 2839, 1606, 1474, 1460, 1449, 823, $760 \mathrm{~cm}^{-1}$; ${ }^{1} \mathrm{H}$ NMR $\left(300 \mathrm{MHz}, \mathrm{CDCl}_{3}\right) \delta 1.17-1.30(\mathrm{~m}, 1 \mathrm{H}, \mathrm{CHH})$, $1.48-1.62(\mathrm{~m}, 1 \mathrm{H}, \mathrm{CHH}), 1.71-1.86(\mathrm{~m}, 1 \mathrm{H}, \mathrm{CHH}), 2.04-2.19(\mathrm{~m}, 2 \mathrm{H}$, $2 \times \mathrm{CHH}), 2.28-2.36(\mathrm{~m}, 1 \mathrm{H}, \mathrm{CHH}), 2.63-2.94\left(\mathrm{~m}, 5 \mathrm{H}, 2 \times \mathrm{CH}_{2}\right.$ and $\left.\mathrm{CH}_{\text {alkylic }}\right), 6.90-6.93(\mathrm{~m}, 1 \mathrm{H}, \mathrm{CH}), 7.04-7.12(\mathrm{~m}, 2 \mathrm{H}, 2 \times \mathrm{CH}) ;{ }^{13} \mathrm{C} \mathrm{NMR}$ $\left(75 \mathrm{MHz} \mathrm{CDCl}_{3}\right) \delta 23.8,26.4,29.3,31.9,35.1,42.1,121.1,125.0,126.4$, 134.0, 143.1, 144.7; MS-EI $(\mathrm{m} / \mathrm{z}): 158\left(\mathrm{M}^{+}, 23 \%\right), 130$ (100), 129 (47), 128 (31), 115 (40). HRMS-EI (m/z): [M] ${ }^{+}$calcd for $\mathrm{C}_{12} \mathrm{H}_{14}, 158.1096$; found 158.1094 .

4.4.10. 5,6,7,8-Tetrahydro-1-naphthalenamine (2k) ${ }^{32}$. Reddish-brown solid, mp 38-40 ${ }^{\circ} \mathrm{C}$; IR (film) 3530, 3470, 3050, 2950, 2850, 1630, $1600,1470,768 \mathrm{~cm}^{-1} ;{ }^{1} \mathrm{H}$ NMR $\left(300 \mathrm{MHz}, \mathrm{CDCl}_{3}\right) \delta 1.70-1.77(\mathrm{~m}, 2 \mathrm{H}$,
$\left.\mathrm{CH}_{2}\right), 1.78-1.86\left(\mathrm{~m}, 2 \mathrm{H}, \mathrm{CH}_{2}\right), 2.41\left(\mathrm{t}, J=6.4 \mathrm{~Hz}, 2 \mathrm{H}, \mathrm{CH}_{2}\right), 2.71(\mathrm{t}$, $\left.J=6.1 \mathrm{~Hz}, 2 \mathrm{H}, \mathrm{CH}_{2}\right), 3.41\left(\mathrm{~s}, 2 \mathrm{H}, \mathrm{NH}_{2}\right), 6.46-6,53(\mathrm{~m}, 2 \mathrm{H}, 2 \times \mathrm{CH}), 6.92$ $(\mathrm{t}, J=7.6 \mathrm{~Hz}, 1 \mathrm{H}, \mathrm{CH}) ;{ }^{13} \mathrm{C} \mathrm{NMR}\left(75 \mathrm{MHz}, \mathrm{CH}_{3} \mathrm{OD}\right) \delta 23.2,23.5,24.0$, 30.1, 113.0, 119.7, 122.5, 125.8, 137.7, 144.8; MS-EI $(m / z): 147\left(\mathrm{M}^{+}, 59 \%\right)$, 146 (25), 132 (14), 131 (13), 130 (16), 119 (100), 118 (32), 115 (12), 106 (12), 91 (19), 77 (13), 65 (10), 51 (10), 39 (13). HRMS-EI (m/z): [M] ${ }^{+}$ calcd for $\mathrm{C}_{10} \mathrm{H}_{13} \mathrm{~N}, 147.1048$; found 147.1051.

4.4.11. 1,2,2a,5-Tetrahydroacenaphthylene ( $3 \boldsymbol{h})^{33}$. Pale yellow oil; IR (film) 3070, 3023, 2962, 2830, 1670, 1632, 1458, $750 \mathrm{~cm}^{-1}$; ${ }^{1} \mathrm{H}$ NMR $\left(300 \mathrm{MHz}, \mathrm{CDCl}_{3}\right) \delta: 1.56-1.88\left(\mathrm{~m}, 2 \mathrm{H}, \mathrm{CH}_{2}\right), 2.32-2.56(\mathrm{~m}, 2 \mathrm{H}$, $\mathrm{CH}_{2}$ ), 3.30 (br s, $3 \mathrm{H}, \mathrm{CH}_{2}$, and $\mathrm{CH}_{\text {alkylic }}$ ), 5.96 (br s, $2 \mathrm{H}, 2 \times \mathrm{CH}_{\text {vinylic }}$ ), 6.80-7.00 (m, 3H, $3 \times \mathrm{CH}) ;{ }^{13} \mathrm{C}$ NMR $\left(75 \mathrm{MHz} \mathrm{CDCl}_{3}\right) \delta: 29.5,32.0$, 34.1, 41.0, 121.5, 124.0, 126.0, 126.3, 130.4, 132.3, 141.8, 142.9; MS-EI $(\mathrm{m} / \mathrm{z}): 156\left(\mathrm{M}^{+}, 85 \%\right), 155(100), 154(15), 153(31), 152(26), 141(60)$, 129 (27), 128 (91), 127 (24), 115 (37). HRMS-EI ( $m / z)$ : [M] ${ }^{+}$calcd for $\mathrm{C}_{12} \mathrm{H}_{12}, 156.0939$; found 156.0945 .

4.4.12. 5,8-Dihydro-1-naphthalenol (3i) ${ }^{34}$. Brown solid, mp 70-72 ${ }^{\circ} \mathrm{C}$; IR (KBr) 3338, 3017, 2840, 1666, 1627, 1462, 1227, $785 \mathrm{~cm}^{-1}$; ${ }^{1} \mathrm{H}$ NMR $\left(300 \mathrm{MHz}, \mathrm{CDCl}_{3}\right) \delta 3.13\left(\mathrm{~d}, J=5.5 \mathrm{~Hz}, 2 \mathrm{H}, \mathrm{CH}_{2}\right), 3.23$ (d, J=5.6 Hz, $2 \mathrm{H}$, $\mathrm{CH}_{2}$ ), 5.19 (br s, $\left.1 \mathrm{H}, \mathrm{OH}\right), 5.70-5.78\left(\mathrm{~m}, 2 \mathrm{H}, 2 \times \mathrm{CH}_{\text {vinylic }}\right), 6.44$ $(\mathrm{d}, J=7.8 \mathrm{~Hz}, 1 \mathrm{H}, \mathrm{CH}), 6.55(\mathrm{~d}, J=7.6 \mathrm{~Hz}, 1 \mathrm{H}, \mathrm{CH}), 6.86(\mathrm{t}, J=7.7 \mathrm{~Hz}, 1 \mathrm{H}$, $\mathrm{CH}) ;{ }^{13} \mathrm{C}$ NMR (75 MHz, $\left.\mathrm{CDCl}_{3}\right) \delta 23.8,29.3,112.0,120.7,121.2,123.7$, 124.2, 126.3, 135.6, 153.0; MS-EI (m/z): $146\left(\mathrm{M}^{+}, 100 \%\right), 145$ (64), 131 (57), 129 (10), 128 (17), 127 (40), 117 (33), 116 (18), 115 (57), 91 (17), 89 (12), 77 (12), 63 (18), 51 (17). HRMS-EI $(m / z)$ : $[\mathrm{M}]^{+}$calcd for $\mathrm{C}_{10} \mathrm{H}_{10} \mathrm{O}$, 146.0732; found 146.0725 .

4.4.13. 1,4-Dihydronaphthalene (3a) ${ }^{35}$. Colorless oil; IR (film) 3062, 3030, 2981, 2866, 2821, 1666, 1580, 1497, 1456, 1426, 1183, 1041, 998, 920, $745 \mathrm{~cm}^{-1}$; ${ }^{1} \mathrm{H}$ NMR $\left(300 \mathrm{MHz}, \mathrm{CDCl}_{3}\right) \delta 3.78(\mathrm{~s}, 4 \mathrm{H}$, $\left.2 \times \mathrm{CH}_{2}\right), 6.30-6.33\left(\mathrm{~m}, 2 \mathrm{H}, 2 \times \mathrm{CH}_{\text {vinylic }}\right), 7.44-7.49(\mathrm{~m}, 4 \mathrm{H}, 4 \times \mathrm{CH})$; ${ }^{13} \mathrm{C}$ NMR (75 MHz, $\left.\mathrm{CDCl}_{3}\right) \delta 29.7,124.7,125.8,128.3,134.2$; MS-EI (m/z): 130 ( $\left.\mathrm{M}^{+}, 100 \%\right), 129$ (74), 128 (45), 127 (17), 115 (38), 51 (10). HRMS-EI $(m / z)$ : $[\mathrm{M}]^{+}$calcd for $\mathrm{C}_{10} \mathrm{H}_{10}, 130.0783$; found 130.0790 .

4.4.14. 5,8-Dihydro-1-naphthalenamine $(\mathbf{3 k})^{36}$. Orange solid; $\mathrm{mp}$ $37-38^{\circ} \mathrm{C}$; IR (KBr) 3470, 3385, 3050, 2853, 1652, 1630, 1470, $761 \mathrm{~cm}^{-1} ;{ }^{1} \mathrm{H}$ NMR $\left(300 \mathrm{MHz}, \mathrm{CDCl}_{3}\right) \delta 3.09-3.12\left(\mathrm{~m}, 2 \mathrm{H}, \mathrm{CH}_{2}\right)$, 3.40-3.45 (m, 2H, CH 2$), 3.58-3.68\left(\mathrm{~m}, 2 \mathrm{H}, \mathrm{NH}_{2}\right.$ ), 5.92 (br s, $1 \mathrm{H}$, $\mathrm{CH}_{\text {vinylic }}$ ), 5.95 (br s, $\left.1 \mathrm{H}, \mathrm{CH}_{\text {vinylic }}\right), 6.56(\mathrm{~d}, J=7.8 \mathrm{~Hz}, 1 \mathrm{H}, \mathrm{CH}), 6.59$ (d, $J=7.8 \mathrm{~Hz}, 1 \mathrm{H}, \mathrm{CH}), 7.01(\mathrm{t}, J=7.6 \mathrm{~Hz}, 1 \mathrm{H}, \mathrm{CH}) ;{ }^{13} \mathrm{C}$ NMR $(75 \mathrm{MHz}$, $\left.\mathrm{CDCl}_{3}\right) \delta 25.0,29.6,112.4,118.9,119.2,123.1,124.7,126.4,134.5$, 143.7; MS-EI ( $\mathrm{m} / \mathrm{z})$ : 145 (M $\left.\mathrm{M}^{+}, 77 \%\right), 144$ (100), 143 (28), 130 (49), 128 (23), 127 (27), 117 (16), $116(15), 115$ (44), 91 (12), 89 (16), 77 (14), 65 (13), 63 (21), 52 (13), 51 (19), 39 (22). HRMS-EI (m/z): [M] $]^{+}$calcd for $\mathrm{C}_{10} \mathrm{H}_{11} \mathrm{~N}, 145.0891$; found 145.0901 .

\section{Acknowledgements}

We thank the CONICET (Consejo Nacional de Investigaciones Científicas y Técnicas, Project PIP 5104) and SGCyT-UNS (Secretaría General de Ciencia y Tecnología-Universidad Nacional del Sur, Project 24/Q026) from Argentina for financial support. F.N. thanks CIC (Comisión de Investigaciones Científicas) from Argentina for a doctoral fellowship. We are grateful to Prof. L. Bengochea (UNS) for XRD analysis. This work was also supported by the Spanish Ministerio de Educación y Ciencia (MEC; grant no. CTQ2007-65218 and Consolider Ingenio 2010-CSD2007-00006) and the Generalitat Valenciana (grant no. PROMETEO/2009/039).

\section{References and notes}

1. (a) Keith, L. H.; Telliard, W. A. Environ. Sci. Technol. 1979, 13, 416-423; (b) Holland, P. T.; Hickey, C. W.; Roper, D. S.; Trower, T. M. Arch. Environ. Contam. 
Toxicol. 1993, 25, 456-463; (c) Rockne, K. J.; Srand, S. E. Environ. Sci. Technol. 1998, 32, 3962-3967; (d) Santodonato, J. Chemosphere 1997, 34, 835-848 and refences cited therein.

2. (a) Poster, D. L.; Schantz, M. M.; Sander, L. C.; Wise, S. A. Anal. Bioanal. Chem. 2006, 386, 859-881; (b) Tao, S.; Li, X. R.; Yang, Y.; Coveney, R. M.; Lu, S. S.; Chen, H. T.; Shen, W. R. Environ. Sci. Technol. 2006, 40, 4586-4591; (c) Menzie, C. A.; Potocki, B. B.; Santodonato, J. Environ. Sci. Technol. 1992, 26, 1278-1284; (d) Northcott, G. L.; Jones, K. C. Environ. Sci. Technol. 2001, 35, 1111-1117.

3. (a) Haritash, A. K.; Kaushik, C. P. J. Hazard. Mater. 2009, 169, 1-15; (b) Meckenstock, R. U.; Safinowski, M.; Griebler, C. FEMS Microbiol. Ecol. 2004, 49 27-36; (c) Chang, B. V.; Shiung, L. C.; Yuan, S. Y. Chemosphere 2002, 48, 717-724; (d) Townsend, G. T.; Prince, R. C.; Suflita, J. M. Environ. Sci. Technol. 2003, 37, 5213-5218; (e) Wammer, K. H.; Peters, C. A. Envrion. Sci. Technol. 2005, 39, 2571-2578

4. (a) Fu, P. P.; Lee, H. M.; Harvey, R. G. J. Org. Chem. 1980, 45, 2797-2803; (b) Barrio, V. L.; Arias, P. L.; Cambra, J. F.; Güemes, M. B.; Pawelec, B.; Fierro, J. L. G. Appl. Catal. A: Gen. 2003, 242, 17-30; (c) Pawelec, B.; Campos-Martin, J. M. Cano-Serrano, E.; Navarro, R. M.; Thomas, S.; Fierro, J. L. G. Environ. Sci. Technol. 2005, 39, 3374-3381; (d) Schüt, C.; Reinhard, M. Appl. Catal. B: Environ. 1998, 18, 215-221; (e) Venezia, A. M.; La Parola, V.; Pawelec, B.; Fierro, J. L. G. Appl. Catal. A: Gen. 2004, 264, 43-51; (f) Yuan, T.; Marshall, W. D. J. Hazard. Mater. 2005, 126, 149-157; (g) Castaño, P.; Pawelec, B.; Fierro, J. L. G.; Arandes, J. M. Bilbao J. Appl. Catal. A: Gen. 2006, 315, 101-113.

5. (a) Bovkun, T. T.; Grayevsky, M.; Sasson, Y.; Blum, J. J. Mol. Catal. A: Chem. 2007, 270, 171-176; (b) Murahashi, S.-I.; Imada, Y.; Hirai, Y. Bull. Chem. Soc. Jpn. 1989, 62, 2968-2976; (c) Wang, W.-B.; Lu, S.-M.; Yang, P.-Y.; Han, X.-W.; Zhou, Y.-G. J. Am. Chem. Soc. 2003, 125, 10536-10537; (d) Fujita, K.; Kitatsuji, C.; Furukawa, S.; Yamaguchi, R. Tetrahedron Lett. 2004, 45, 3215-3217; (e) Lynch, T. J.; Banah, M.; Kaesz, H. D.; Porter, C. R. J. Org. Chem. 1984, 49, 1266-1270; (f) Zhou, Y.-G. Acc. Chem Res. 2007, 40, 1357-1366.

6. (a) Hishoyi, N.; Osada, M.; Rode, C. V.; Sato, O.; Shirai, M. Appl. Catal. A: Gen. 2007, 331, 1-7; (b) Zhou, X.; Wu, T.; Hu, B.; Jiang, T.; Han, B. J. Mol. Catal. A: Chem. 2009, 306, 143-148; (c) Jacinto, M. J.; Santos, O. H. C. F.; Landers, R.; Kiyohara, P. K.; Rossi, L. M. App. Catal. B: Environ. 2009, 90, 688-692; (d) Nelkenbaum, E.; Dror, I.; Berkowitz, B. Chemosphere 2007, 68, 210-217.

7. (a) Harvey, R. G.; Arzadon, L.; Grant, J.; Urberg, K. J. Am. Chem. Soc. 1969, 91, 4535-4541; (b) Bendeser, R. A.; Belmonte, F. G.; Kang, J. J. Org. Chem. 1983, 48, 2796-2802; (c) Birch, A. J. Pure Appl. Chem. 1996, 68, 553-556; (d) Rabideau, P. W. Tetrahedron 1989, 45, 1579-1603; (e) Katritzky, A. R.; Rachwal, S.; Rachwal, B. Tetrahedron 1996, 52, 15031-15070.

8. For a recent review, see: López Ortiz, F; Iglesias, M. J.; Fernández, I; Andújar Sánchez, C. M.; Ruiz Gómez, G. Chem. Rev. 2007, 107, 1580-1691.

9. (a) Stutz, A.; Georgopoulos, A.; Granitzer, W.; Petranyi, G.; Berney, D. J. Med. Chem. 1986, 29, 112-125; (b) Cimetiere, B.; Dubuffet, T.; Landras, C.; Descombes, J.-J.; Simonet, S.; Verbeuren, T. J.; Lavielle, G. Bioorg. Med. Chem. Lett. 1998, 8, 1381-1386; (c) Dumas, M.; Dumas, J. P.; Bardou, M.; Rochette, L.; Advenier, C.; Giudicelli, J. F. Eur. J. Pharmacol. 1998, 348, 223-228.

10. Shao, J.: Song, C. Catal. Today 2001, 65, 59-67 and references cited therein.

11. (a) Aiken, J. D.; Finke, R. G. J. Mol. Catal. A: Chem. 1999, 145, 1-44; (b) Kim, F.; Song, J. H.; Yang, P. J. Am. Chem. Soc. 2002, 124, 14316-14317; (c) Bell, A. T. Science 2003, 299, 1688-1691; (d) Daniel, M. C.; Astruc, D. Chem. Rev. 2004, 104, 293-346.

12. (a) Deng, J.-P.; Shih, W.-C.; Mou, C.-Y. J. Phys. Chem. C 2007, 111, 9723-9728; (b) Bianchini, C.; Dal Santo, V.; Meli, A.; Moneti, S.; Psaro, R.; Sordelli, L.; Vizza, F. Inorg. Chim. Acta 2008, 361, 3677-3680; (c) Deng, J.-P.; Shih, W.-C.; Mou, C.-Y. Chem. Phys. Chem. 2005, 6, 2021-2025.

13. For NiNP-promoted reactions see: Reviews. (a) Alonso, F.; Radivoy, G.; Yus, M. Russ. Chem. Bull. 2003, 52, 2563-2576; (b) Alonso, F.; Yus, M. Chem. Soc. Rev. 2004, 33, 284-293; (c) Alonso, F.; Yus, M. Pure Appl. Chem. 2008, 80, 1005-1012
See also: (d) Alonso, F.; Riente, P.; Yus, M. Synlett 2008, 1289-1292; (e) Alonso, F: Riente, P. Yus, M. Eur. J. Org. Chem. 2008, 4908-4914; (f) Alonso, F. Riente, P.; Yus, M. Synlett 2009, 1579-1582; (g) Alonso, F.; Riente, P.; Yus, M. Tetrahedron Lett. 2009, 50, 3070-3073; (h) Alonso, F.; Riente, P.; Yus, M. Eur. J. Org Chem. 2009, 6034-6042; (i) Alonso, F.; Riente, P.; Yus, M. Tetrahedron. 2009, 65 , 10637-10643; (j) Alonso, F.; Riente, P.; Sirvent, J. A.; Yus, M. Appl. Catal. A: Gen. 2010, 378, 42-51.

14. For FeNP-promoted reactions see: (a) Moglie, Y.; Alonso, F.; Vitale, C.; Yus, M.; Radivoy, G. Tetrahedron 2006, 62, 2812-2819; (b) Moglie, Y.; Alonso, F.; Vitale C.; Yus, M.; Radivoy, G. Appl. Catal. A: Gen. 2006, 313, 94-100; (c) Moglie, Y. Vitale, C.; Radivoy, G. Tetrahedron Lett. 2008, 49, 1828-1831.

15. For CuNP-promoted reactions see: (a) Alonso, F.; Vitale, C.; Radivoy, G.; Yus, M. Synthesis 2003, 443-447; (b) Radivoy, G.; Alonso, F.; Moglie, Y.; Vitale, C.; Yus, M. Tetrahedron 2005, 61, 3859-3864; (c) Alonso, F.; Moglie, Y.; Radivoy, G.; Yus, M. Tetrahedron Lett. 2009, 50, 2358-2362; (d) Moglie, Y.; Mascaró, E.; Nador, F.; Vitale, C.; Radivoy, G. Synth. Commun. 2008, 38, 3861-3874; (e) Nador, F.; Fortunato, L.; Moglie, Y.; Vitale, C.; Radivoy, G. Synthesis 2009, 4027-4031; (f) Alonso, F.; Moglie, Y.; Radivoy, G.; Yus, M. Eur. J. Org. Chem. 2010, 1875-1884. 16. Radivoy, G.; Alonso, F.; Yus, M. Tetrahedron 1999, 55, 14479-14490.

17. For reviews on the application of transition-metal nanoparticles in catalysis, see: (a) Roucoux, A.; Schulz, J.; Patin, H. Chem. Rev. 2002, 102, 3757-3778; (b) Johnson, B. F. G. Top. Catal. 2003, 24, 147-159; (c) Moreno-Mañas, M.; Pleixats, R. Acc. Chem. Res. 2003, 36, 638-643; (d) Astruc, D.; Lu, F.; Ruiz Aranzaes, J. Angew. Chem., Int. Ed. 2005, 44, 7852-7872; (e) Migowski, P.; Dupont, J. Chem.Eur. J. 2007, 13, 32-39; (f) Metal Nanoclusters in Catalysis and Materials Science The Issue of Size Control; Corain, B., Schmid, G., Toshima, N., Eds.; Elsevier: Amsterdam, 2008.

18. All attempts to reduce 1 - or 2-acetylnaphthalene, 1-nitronaphthalene, 1 naphthoic acid, and 2-methylnaphthalene with either the CoNP- or the MnNPbased reducing systems, proceeded with very low conversions of the starting materials (ca. 10-15\%) to give complex mixtures of products.

19. Alonso, F.; Beletskaya, I. P.; Yus, M. Chem. Rev. 2002, 102, 4009-4091.

20. (a) Furimsky, E. Appl. Catal. A: Gen. 2000, 199, 147-190; (b) Shirai, M.; Rode, C. V.: Mine, E.; Sasaki, A.; Sato, O.; Hiyoshi, N. Catal. Today 2006, 115, 248-253.

21. (a) Maercker, A. Angew. Chem., Int. Ed. Engl. 1987, 26, 972-989; (b) Yus, M.; Foubelo, F.; Ferrández, J. V.; Bachki, A. Tetrahedron 2002, 58, 4907-4915.

22. For reviews on carbon-fluorine bond activation, see: (a) Kiplinger, J. L.; Richmond, T. G.; Osterberg, C. E. Chem. Rev. 1994, 94, 373-431; (b) Burdeniuc, J. Jedlicka, B.; Crabtree, R. H. Chem. Ber. Recueil 1997, 130, 145-154.

23. (a) Guijarro, D.; Yus, M. Tetrahedron 2000, 56, 1135-1138; (b) Yus, M.; Herrera R. P.; Guijarro, A. Tetrahedron Lett. 2003, 44, 5025-5027.

24. Perrin, D. D.; Amarego, W. L. F. Purification of Laboratory Chemicals; Pergamon: Oxford, 1988

25. Al-Azawe, S.; Sarkis, G. Y. J. Chem. Eng. Data 1973, 18, 109-111.

26. Sun, L.-B.; Zong, Z.-M.; Kou, J.-H.; Zhang, L.-F.; Ni, Z.-H.; Yu, G.-Y.; Chen, H.; Wei, X.-Y. Energy Fuels 2004, 18, 1500-1504.

27. Ma, Y.-M.; Wei, X.-Y.; Zhou, X.; Cai, K.-Y.; Peng, Y.-L.; Xie, R.-L.; Zong, Y.; Wei, Y.-B.; Zong, Z.-M. Energy Fuels 2009, 23, 638-645.

28. Friedman, S.; Metlin, S.; Svedi, A.; Wender, I. J. Org. Chem. 1959, 24, 1287-1289.

29. Weil, T. A.; Friedman, S.; Wender, I. J. Org. Chem. 1974, 39, 48-50.

30. Srikrishna, A.: Reddy, T. J.: Viswajanani, R. Tetrahedron 1996, 52, 1631-1636.

31. Yu, J. S.; Ankianiec, B. C.; Nguyen, M. T.; Rothwell, I. P. J. Am. Chem. Soc. 1992, 114, 1927-1929.

32. Spectroscopic properties were compared with those of the corresponding commercially available pure sample (Aldrich).

33. Yasuda, M.; Pac, C.; Sakurai, H. J. Org. Chem. 1981, 46, 788-792.

34. Eastham, J. F.; Larkin, D. R. J. Am. Chem. Soc. 1958, 80, 2887-2893.

35. Pétrier, C.; Suslick, K. Ultrason. Sonochem. 2000, 7, 53-61.

36. Watt, G. W.; Knowles, C. M.; Morgan, L. O. J. Am. Chem. Soc. 1947, 69, 1657-1659. 